\title{
Democratic Legitimacy and the Competence Obligation
}

\section{[Forthcoming in Moral Philosophy and Politics]}

\begin{abstract}
What obligations are there on voters? This paper argues that voters should make their electoral decision competently, and does so by developing on a recent proposal for democratic legitimacy. It then explores three problems arising from this ‘competency obligation'. First, how should voters be competent? I propose three conditions required for voter competence. Second, how competent should voters be? I argue that that the competency required tracks the significance of the consequences of the vote. The threshold for competency can therefore be high or low. Third, if the electorate are unlikely to deliver a competent decision, should suffrage be restricted to the competent alone? I defend unrestricted suffrage on the grounds that restricting suffrage cannot guarantee a competently made electoral decision. Instead, obligations on voters should be minimised by political parties satisfying their obligations to be politically sound; if they are sound, then the obligation to be competent can be easily satisfied by voters.
\end{abstract}

Keywords: Elections; Democratic Legitimacy; Competence; Suffrage; Voter Obligations.

\section{Introduction}

Modern representative democracies grant voting rights to the majority of their citizens. But what obligations, if any, does the right to vote place on voters? This paper argues for one component to voter obligation, which arises from a recent account of democratic legitimacy. It then explores the consequences of this obligation for the issue of who should have the right to vote.

The recent account of democratic legitimacy, developed by Jason Brennan (2011; 2016), maintains that the decision-makers in a democratic procedure must be sufficiently competent to make the required decision, and must arrive at the decision in a sufficiently competent way. The competence of the decision-makers concerns their moral character, their epistemic capacities, and their relevant knowledge base. Arriving at the decision in a competent way requires the decisionmakers to make the decision in a morally appropriate way, and to properly base their decision on relevant epistemic grounds. Only if these conditions are satisfied, according to this theory, will the democratic decision be legitimate. In a representative election, then, we can derive the following obligation: voters should be sufficiently competent - both morally and epistemically - and should make their decision in a sufficiently competent way. Call this the competence obligation. 
Although I agree with the central argument for the view that competence is required for democratic legitimacy, critical assessment of the argument reveals several outstanding and subsidiary problems. In this paper I address three of these issues in order to determine whether, and to what extent, the competence obligation holds, and the significance it has for voting rights.

First, it's not entirely clear how voters should be competent. What knowledge is relevant to voter competence? In what way should voters be moral? I derive three principles that constitute the competence obligation, and explore what evidence and facts should be sought for voters to be epistemically competent.

Second, it's not clear how competent voters should be. Moral and epistemic competence comes in degrees, so we need to know what the thresholds are for competence in order that democracy be legitimate. My position on this will be that the competence required for legitimacy tracks the significance of the consequences of the vote. If the outcome of the vote will have significantly negative or positive consequences, then the competence of the voters must be relatively higher than it would be if the outcome of the vote would have insignificant consequences. A way of minimising the consequences of the vote comes from what I call the political soundness of both the political parties that voters can choose from, and the political environment citizens are voting within. 'Political soundness' concerns the justification of the policies chosen by the political parties, and the justness of the institutions constitutive of the political system, such as the rule of law and the freedom of the press. When political soundness is high, I propose that voters need only have low competence, but when political soundness is low, the voters need to have higher levels of competence.

The third issue I address follows from the second. Given what has been argued concerning democratic legitimacy, it seems that there will be cases where a democracy constituted by unrestricted suffrage would be illegitimate - where the competence of the voters would be insufficient to render the vote legitimate. ${ }^{1}$ If that's the case, then should voting rights be restricted from some to ensure we can arrive at legitimate decision-making? Advocates of this position are advancing varieties of

\footnotetext{
${ }^{1}$ In modern democracies, suffrage is restricted only for reasons that are commonly thought to be justified. This means that voting rights are not withheld for arbitrary reasons like race, social class or gender, but only on non-arbitrary grounds such as age, and are therefore distributed as widely as is thought to be reasonable. Suffrage is unrestricted in this normative sense. No democratic system currently offers completely unrestricted or universal suffrage, i.e. voting rights to every person in the nation.
} 
what has come to be called epistocracy. ${ }^{2}$ I argue that restricting suffrage to the competent won't ensure arriving at legitimate decision-making. If citizens are unlikely to fulfil their obligations qua voters, rather than taking away their voting rights, I propose that more needs to be done to ensure that voters can fulfil their obligations. One of the ways to do this is to alter the contextual factors in such a way that there are lower levels of obligations on voters, namely, by reducing the significance of their vote by improving political soundness.

Finally, I propose that if the level of obligation on voters is low, that needn't give voters a reason to be disinterested in politics. One reason is because taking an interest in political affairs, even when their obligations to be competent are low, will lead to greater soundness within political parties and institutions.

In $\$ 2$ of this paper, I outline and defend the central argument for the competence obligation, which I derive from the work of Brennan. In \$3.1, I explore the first problem by giving an account of how voters should be competent. In \$3.2, I explore the second problem by defending my account of how competent voters should be, in that their competence tracks the significance of the vote. In $\$ 4$, I explore the third problem by defending unrestricted suffrage, and by showing why voters ought to take an interest in political affairs. This discussion builds on the work from $\$ 3.2$ by looking particularly at the obligation on political parties to be politically sound.

\section{Democratic Legitimacy and Competence}

Governments wield massive amounts of authority over citizens. They determine the rights that citizens have, decide how to tax citizens and how to spend that tax, and coerce the behaviour of citizens through law and enforcement. Despite this, it's often argued that the state's authority can be legitimised if it satisfies certain conditions. That is, it can be that the people living under the state's authority have an obligation to obey its authority. Most notably, it is argued that this is only the case if the citizens under authority get to vote for which government comes into power through a fair democratic process (Waldron 1998, p. 310). ${ }^{3}$ Only if citizens get a say in who has political authority over them, it is often argued, will that authority be legitimate - will the citizens be

\footnotetext{
2 Epistocracy, or 'the role of the knowledgeable', has its roots in Plato's Republic. The term was coined by Estlund (2003). A form of epistocracy was advanced by Mill (1991), and others have recently been proposed by Brennan (2016) and Mulligan (2018).

${ }^{3}$ The existence of states in general can be justified through various arguments, for instance, the State of Nature tradition associated with Hobbes and Locke. Nevertheless, a particular state must meet certain requirements if it is to be legitimate.
} 
required to obey the state's laws. ${ }^{4}$ But what is it about the democratic process of electing political authority that legitimises that authority?

Theories of democratic legitimacy cut across two dimensions: instrumental and procedural. Instrumental accounts maintain that democracy is legitimate because it makes correct decisions. For instance, the original formulation of the Condorcet jury theorem argues that the greater the number of voters, the higher the probability that the majority vote will yield the right answer. More recently, Landemore (2012) provides evidence that decision-making mechanisms which bring together diverse perspectives outperform decision-making by groups that are less diverse, for instance, by groups of experts. Extending either of these views to a political election, it would follow that political authority is made legitimate by the electoral decision when the decision is made correctly. In contrast, proceduralist accounts maintain that democracy is a legitimate process for granting political authority because its decisions are the result of an appropriately constrained process of decision-making. Accounts vary on what it is to be 'appropriately constrained', for instance, whether the process is procedurally fair (May 1952), or the quality of the process of public deliberation leading to the decision (Bohman 1996; Manin 1987).

Instrumentalist and proceduralist accounts can be combined to create hybrid theories of legitimacy. For instance, David Estlund (2008) proposes that democratic legitimacy is the result of procedures that tend to make correct decisions. He calls this 'epistemic proceduralism'. A central example that elaborates epistemic proceduralism is the jury decision. Jury decisions are authoritative because they're arrived at through a procedure that tends to make correct decisions. So, even if a particular jury verdict is incorrect, the jury's decision is still legitimate, and because of this, its authority is binding on the defendant. This account holds that electoral decisions are legitimate and hence authoritative because they tend to be correct, rather than because any particular decision is correct.

Working within this kind of hybrid framework of legitimacy, we can argue that there must be constraints on the procedure in question if it is to be legitimate. A highly plausible proposal for such a constraint is that juries must be competent and must make their decision competently. This point has been defended recently by Jason Brennan. To make this point he develops several examples of juries that are unjust due to failures of competence (2011, pp. 703-10; 2016, pp. 15162). He asks us to imagine that a jury is deciding the fate of a defendant convicted of murder. If the jury bases its decision on any one of five clearly unjustified reasons then the jury's decision is

\footnotetext{
${ }^{4}$ Note that this is a necessary but not sufficient condition for legitimacy. There may be other conditions required. For instance, that the citizens consent to the authority (Pitkin 1965; 1966), and that the authority is voted for through a process involving public deliberation (Cohen 1997).
} 
illegitimate, and it is unjust to convict someone on the basis of the jury's verdict. The five kinds of juries Brennan considers are those that are ignorant, irrational, impaired, immoral and corrupt.

Ignorant juries pay no attention to the evidence in the trial, but find the defendant guilty arbitrarily on something like a coin toss. Irrational juries follow the evidence given in a trial, but decide that the defendant is guilty in a way unrelated to the evidence, perhaps basing it on wishful thinking or odd conspiracy theories. Impaired juries pay attention during the trial but aren't cognitively competent enough to process what they hear and so don't understand it, deciding that the defendant is guilty at random or on guesswork. Immoral juries follow the evidence in the trial but find the defendant guilty on the basis of prejudice or bias, for instance, finding the female defendant guilty whilst harbouring severe prejudices against women. Corrupt juries find the defendant guilty on the basis of bribery rather than the evidence presented at the trial. ${ }^{5}$

In each of these cases, it looks unjust to enforce the jury's guilty verdict because they have arrived at the verdict in an illegitimate way. In some cases, these are failures of epistemic competence. For instance, the ignorant jury are unaware of the relevant facts, the irrational jury are consumed with odd conspiracy theories, and the impaired jury lack the cognitive capacity to process the complex information presented to them. Because of their epistemic incompetence, the ignorant, irrational and impaired juries base their guilty verdict on reasons irrelevant to the potential guilt or innocence of the defendant. And due to this unjustified basing, the decision arrived at is illegitimate. The same is true when the jury lack moral competence. The immoral jury are riddled with prejudices and biases, and the corrupt jury has been paid off to vote a particular way. There is a failure to base verdicts on the relevant facts in both of these cases, making the decision illegitimate. ${ }^{6}$

Since these decisions are illegitimate, they lack any binding authority over the defendant the defendant has no obligation to follow the result of the jury decision. And if the jury verdict is upheld, then it would be unjust to punish the defendant on the basis of the illegitimate decision

\footnotetext{
5 There's a symmetry in this argument with doxastic justification in epistemology. To have doxastic justification for a proposition believed, a person must have sufficient evidence to believe that proposition, and base her belief on the evidence (Silva 2015). Symmetrically, for the jury's decision to be legitimate, they must have sufficient grounds for the verdict, and base their decision on those grounds. In each of the five cases, they consistently fail to meet the condition in the second conjunct - the basing-condition - and in some cases they fail to satisfy the first as well.

${ }^{6}$ Perhaps those seeking to justify the rule of the knowledgeable - epistocracy - are focussed too narrowly. What we may require instead is an aretocracy - the rule of the virtuous, including both the moral and intellectual virtues.
} 
made by the jury. Particularly so given that the consequences of the verdict will do significant harm to her liberty and wellbeing. ${ }^{7}$

From the examples of the unjust juries, Brennan argues for what he calls 'the competence principle':

It is presumed to be unjust, and to violate a citizen's rights, to forcibly deprive a citizen of life, liberty, or property, or to significantly harm their life prospects, as a result of decisions made by an incompetent deliberative body, or decisions made in an incompetent way or in bad faith. Political decisions are presumed legitimate and authoritative only when produced by competent political bodies in a competent way and in good faith. (2016, p. $156-57)^{8}$

Four points are worth noting concerning the competence principle. First, as we said above, 'competence' ought to be read broadly to encompass both epistemic and moral competence. Second, the principle only applies in cases in which the decisions being made will lead to forcibly depriving a citizen, or citizens, of life, liberty, or property, or to the significant harm of their life prospects. Third, I take the principle to be necessary but not sufficient for legitimacy. It merely spells out conditions on what the competence of the decision-makers ought to be, and how competently the decision ought to be made. There can still be further conditions set out, say, that the procedure is fair, or that the decision is made in a way that for other reasons usually yields the right result. That said, the converse also holds, namely that a failure to comply with the competence principle would be sufficient but not necessary for democratic illegitimacy.

Fourth, the final clause takes the decision to apply not only to jury decisions, but to political decisions as well. This involves decisions made by politicians. But crucially, and for our interests here, it is also taken to apply to the decision made by the public in a political election. We need to look more closely at this fourth point to make a positive case for a competence obligation on voters.

\footnotetext{
${ }^{7}$ Note how this is an epistemically proceduralist conception of legitimacy since the outcome does not need to be correct. What matters is the process of arriving at the decision in a way that tends to yield correct results. Competent juries tend to get the result right, but they could get the conviction wrong. If they do, provided it was made competently, the decision is still authoritative, though unjust. And incompetent juries can also get the conviction right, if they just guess. But if they do, on this account, their decision is not authoritative.

${ }^{8}$ There is a particular version of this given for juries in Brennan's 2016 (pp. 153-54). For simplicity I have only given the generalised version, which applies to any deliberative body, including both juries and representative democracies.
} 
In order to extend the competence principle to representative elections, Brennan considers the example of electing the Nazi party to power in Germany in 1933:

We should not underestimate the damage bad voting can do. Bad voting can be and has been disastrous... The voters who put the National Socialists in power in Germany in 1933 cannot be held responsible for everything their government did. But much of what their government did was foreseeable by any reasonably well-informed person, and so their supporters were blameworthy. (2011, p. 707; c.f. 2016, p. 159)

Now, undoubtedly the decision of the German electorate led to the forcible deprivation of citizens' life, liberty, and property, and to significant harm of their life prospects. But is this an electoral decision to which we can extend the competence principle? Brennan seems to maintain the somewhat controversial claim that if the German electorate in 1933 were 'reasonably wellinformed' then they would have had the foresight to predict what the Nazi party would have done. Because they were not well-informed then, for Brennan, they are blameworthy for bringing the Nazi party into power. Instead, they ought to have been properly informed about the facts of that election. And if this claim is correct, then this seems like a case to which we can apply the competence principle because it's open to similar considerations as the jury case. It then follows that, for the election of the Nazi party in Germany in 1933 at least, the electorate's decision was illegitimate, and it was unjust to implement the result.

Brennan's argument provides us with two general problems for extending the competence principle to representative elections. First, are elections always high stakes in the requisite sense? Do they always concern the forcible deprivation of citizens' life, liberty, or property, or to their wellbeing? Second, to what extent must voters be competent if they are to avoid making illegitimate electoral decisions. I'll briefly take up the first problem here, and in the next section, will address the second problem.

The competence principle is defended by analogy with a jury trying a defendant for murder. In the jury case, it is obvious that their decision concerns the life, liberty, property and wellbeing of the defendant. But is this the case with general elections? A reason to think that it is, is because governmental policies generally have a negative impact on some people or groups in society. This is particularly the case under conditions of scarcity (Rawls 1999, \$22), which virtually all governments must work within: there is always a balancing act to negotiate between budgetary constraints, taxes, borrowing, and the needs of citizens. Due to this, some budgets must be cut, with a correspondingly negative impact on citizens in society. It can lead to joblessness, reduction in health and social care funding, and limited provision for schools and other public services. 
As a current example, consider the economic circumstances facing the UK government following the 2008 financial crash. The Conservative-led government elected in 2010, in coalition with the Liberal Democrats, faced both huge debt and a significant financial deficit. In order to address this, they committed to a policy of austerity to reduce the debt and the deficit. This involved making cuts across most government departments, including to health and social care. This austerity policy continued for several further years, seeing the Conservatives elected with a majority in 2015.

Now, consider the options facing the voters in the UK during the 2017 general election. One could argue that whether or not the Conservative party was re-elected would have the kind of impact required by the competence principle. This could be argued from an article published in August 2017, which linked the austerity policy of the Conservative party to a sharp increase in deaths. Watkins et al. (2017, p. 6) argued that 'recent constraints in [healthcare] and [social care] spending in England were associated with nearly 45000 higher than expected numbers of deaths between 2012 and 2014.' This 2009-2014 projection, reflecting the decrease in health and social care funding, was compared with a projection of deaths given the rate of health and social care funding from 2001-2010, before there was any decrease. The report adds 'that the 2009-2014based projection entailed an additional 152141 deaths...from 2015 to 2020 compared with the 2001-2010-based projection' (p. 5), where funding would not have decreased.

Now, in the 2017 general election, Labour committed to ending Conservative austerity measures and to put the funding for health and social care back into place, whereas the Conservative party made no such similar pledge. Hence, it seems possible to argue that electing Labour into power in 2017 would prevent circa 50'000 deaths forecast to arise from Conservative austerity measures. If that were the case, and the electorate voted for the Conservative party, then their vote would concern the life and wellbeing of many people in the UK. So, these kinds of considerations give some justification to the view that electing governments involves forcibly depriving some citizens of life, liberty, or property, or to significantly harming their life prospects.

This example may be an exaggeration of the influence of voting, particularly if the claims being made by Watkins et al. are not defensible. But it does show that electing one party to power has an influence over how a country is governed. Perhaps electing the Labour party to power would have increased health and social care spending. Now, I have not selected this example to indicate political partiality, or to judge the policies of UK political parties. It simply shows that electing governments is subject to the competence principle since that political act can bring harm or good for life, liberty, property and wellbeing. And if that's right, then there's a clear obligation on voters to be competent and to make their decision competently. This is what, in the 
introduction, I called 'the competence obligation'. In the next section, we will consider further the nature and extent of the requisite voter competence.

\section{The Competence Obligation}

\subsection{How Should Voters be Competent?}

The five examples of unjust juries that Brennan proposes give us an indication of what is required of juries if their decision is to be competent. There are three components to the competence required. The jury must:

(1) Pay attention to the evidence and facts relevant to the trial.

(2) Process this evidence in a rationally competent way,

which means both having the cognitive capacity to process the relevant evidence, and not being led by prejudices and biases that cause the jury member to misinterpret evidence in unfairly negative or positive ways (cf. Mele 2006, pp. 110-11). The jury must also:

(3) Base their decision on this competence.

It's no good carefully working out in a fully rational way that the defendant is guilty, only to make your final decision on the toss of a coin. Nor should the person base their decision on the bribery of someone else with vested interests in the outcome of the jury decision, nor simply convict the defendant so as to harm her because, for instance, the jury dislike people of her race or gender. The jury must be competent, in line with (1) \& (2), and base their final decision on competent reasoning.

Most of these points can be applied straightforwardly to electoral decisions. (2) \& (3) can be set out in the following principles:

Epistemic Capability: Voters must have the cognitive capacity to process the relevant evidence, and must not be led by prejudices and biases, which cause them to misinterpret evidence in unfairly negative or positive ways. (Representing (2)).

Proper Basing: Voters must base their decision on competent reasoning. (Representing (3)).

These principles represent (2) \& (3). But what is required of voters to satisfy (1), especially as it concerns 'relevant evidence and facts'? What evidence and facts are relevant to the competence required by voters?

To address these questions, it should be noted that the discussion thus far has assumed a position concerning the nature of voting. Recall that one of the justifications for granting citizens the right to vote was that they could choose which government has authority over them. A 
background assumption made by this idea is that a vote is a resource in the hands of a citizen that she can use to influence the outcome of an election. This theory of the nature of voting has been defended by Christiano:

To have a vote in an election is to have certain resources that can be used. To say that someone received your vote is to say that your vote was used to advance that person's prospects of winning the election. The active feature of voting is captured by the fact that the vote must be used by the person to advance whichever alternative she wishes to advance. (Christiano 1995, p. 412)

On this account, a vote is a resource that the citizen uses to bring about a particular state of affairs, namely, that the government she wishes to be in power comes into power. ${ }^{9}$ Of course this can be thwarted when she is outvoted, but nevertheless, the vote was used as a resource in an attempt to bring into power a certain government.

Why ought a voter desire for a particular government to be elected? Two responses to this question are generally thought to be warranted. First, if she altruistically desires for the government to come into power that she believes will be of most benefit to the interests of the citizens in the nation as a whole. ${ }^{10}$ Second, if she egoistically desires for the government to come into power that she believes will be of most benefit to her own interests. ${ }^{11}$

The goal for the voter is then to determine what is in her best interests, or in the interests of the nation, or perhaps a mix of these two, and then gather evidence to help her to determine which political party in a general election is mostly likely to bring about the desired outcome. Alvin Goldman (1999) offers an account of voting and voter knowledge along similar lines. The interests the voter would like to see come about Goldman calls the 'outcome set', and is determined by several variables, for instance, the desirable level of employment, cost of living, provision of health care, crime rate, and environmental quality. The voter then faces 'the core voter question': which of the available parties or candidates would, if elected, produce a better outcome set from my point of view? The aim, then, for the voter is to assess the evidence to answer this question. And when

\footnotetext{
${ }_{9}^{9}$ For an alternative account that treats a vote like an expression of support akin to a speech act, see Brennan and Lomasky (1993).

${ }^{10}$ Voting for the 'common good' can be traced to Rousseau (1997).

${ }^{11}$ Lever (2016) argues that it is permissible for voters to not vote for the common good, and Saunders (2012) that self-interest is allowed some place in the political arena, at least where justice or the common good is indeterminate.
} 
the voter gathers the evidence relevant to answering it, Goldman says the voter has 'core voter knowledge':

In a particular election, then, we assume that one of the answers to voter $V$ s core voter question is true and the other is false. If $V$ believes the true answer, $V$ has core knowledge (in this election). If $V$ believes the false answer, $V$ has core error. If $V$ has no opinion, $V$ has core ignorance. (Goldman 1999, p. 324)

We have been considering what evidence and facts are relevant to the competence required by voters. Goldman's notion of core voter knowledge as it relates to the core voter question seems like a promising suggestion. However, a caveat is in order here. If we require the voter to have core voter knowledge in order to be competent, then we require her to make an assessment of the evidence available in answering the core voter question and to get that question correct. But this stands in tension with the framework of epistemic proceduralism we have been working within: it's not the correct result that makes democracy legitimate, but following a procedure that tends to produce correct results.

With this caveat in mind, the following seems like a more consistent principle for voter competence (in addition to (2) \& (3)):

Epistemic Competence: Voters must reasonably assess the evidence relevant to determining which available parties or candidates would, if elected, produce a better outcome set from their point of view (either egoistically or altruistically, or both), and come to a reasoned belief about this. (Representing (1)).

Note that the relevant evidence will differ between voters as determined by their variable interests.

Before moving on, we need to address an important objection. Suppose someone's interests are deeply immoral and concern serious harm done to other members of society. For instance, if someone will be benefitted from the forcible and unjust removal of an entire ethnic group from society. This may be the kind of case Brennan has in mind when he considers the election of the Nazi party. Someone could satisfy the 'Epistemic Competence' principle above by correctly identifying which political party will bring about this terrible end. Of course that's true, but it wouldn't make their vote for that party competent all things considered. For, they will fail to satisfy the 'Epistemic Capability' principle. It would be akin to the jury convicting someone for murder because they dislike people from her race or gender. To be competent one must satisfy all three of the principles required for competence.

\subsection{How Competent Should Voters Be?}


We have derived three principles that a voter should satisfy if she is to be considered competent. But these principles are vague and so are not entirely informative. Take 'Epistemic Capability', for instance. To what extent must voters have cognitive capacity? Or consider 'Epistemic Competence'. How far should voters 'reasonably assess' the relevant evidence to count as competent? My suggestion in this section is that the competence required by these principles tracks the possible consequences of an electoral decision. To see this, I want to begin with an example which shows that no matter which way the electorate vote, there will be little by way of significant change in terms of the life, liberty, property and wellbeing of the people governed. This will be the case if it is largely not possible for an elected government to either (a) harm the people that it governs, or (b) improve the life prospects of the people that it governs. In what follows, in the interests of limited space, we'll only consider when this is the case from the perspective of (a), though a similar case can be made for (b).

Imagine that two political parties - A \& B - are standing for election. They each have different policies, but all of their policies are designed to improve the life, liberty, property and wellbeing of the people that they govern. Moreover, all of the policies are plausible and carefully justified by the political parties that have designed them. Add to this that the political institutions and frameworks that governments must work within require extensive accountability. For example, that a government must defend each major policy or economic decision that it takes, and face having such policies and decisions outvoted by other parties, and by members of their own party, if these policies and decisions are unfair, unjust or unwarranted. What's more, the politicians constituting each political party are highly competent, both morally and intellectually, and are held publicly to account for their decisions and are scrutinised by a highly competent free press.

In this example, whichever political party gains power will be constrained in the harm they can do to the governed since they must make their decisions within a framework involving extensive accountability. In some actual governments, there are constitutional restrictions on the state's activity. For instance, the First Amendment of the US constitution prevents the government from harming certain rights and freedoms of its citizens. Moreover, the political party that gains power will lack the motivation to intentionally harm the governed. They all have justified policies aimed at improving the lives of the governed, and they are highly competent in their ability to implement their policies.

Note how the decision the electorate must make in this example is importantly different from the jury case. In the jury case, there is a significant difference for the defendant if they submit a verdict of guilt rather than innocence. This is not the case for the election example considered here, since, whichever party gains power, the prospects of the electorate will not significantly differ. 
That is, the future state of affairs for the governed will be largely similar whether it is party A or B that is voted into power.

Here's what I'm not saying: under political party A or B, the living situation of the governed will be the same. For instance, the ideologically conservative-leaning party, A, and the labour-leaning party B, will bring about the same situation for the nation. That's clearly not true. Parties that are ideologically conservative or labour will implement their policies in different ways from each other, meaning different tax rates, more or less provision for social housing, more or less power for unions, etc. What will be similar, though, are the life prospects for the governed in the very general terms of life, liberty, property and overall wellbeing. These things will not be significantly affected whichever party gets into power under the conditions I have proposed. We might say that there will be relative equality for the governed in the very general terms of life, liberty, property and overall wellbeing, regardless of the outcome of the election.

To help to see this point, it's worth suggesting some very rough conditions under which, in my view, very little would be different for the governed in general terms of life prospects, whichever way they vote. We can separate out some of the conditions suggested by the above example in the following way: ${ }^{12}$

Justified Policies: The political parties under consideration must all have carefully justified policies, either directly or indirectly aimed at improving the life, liberty, property and wellbeing of the people that they would govern if elected.

Just Institutions: The political institutions the government will operate within must be transparent and internally democratic, involving a division of power between the institutions and requiring major decisions to be publicly justified.

Political Competence: The politicians involved in each party must be both morally and intellectually competent enough to execute the policies their party supports. ${ }^{13}$

\footnotetext{
12 These conditions are a broad sketch which align roughly with many traditional Republican and liberal tenets. They bear similarity to some of the constitutional conditions Pettit (1997, Chapter 6) discusses. He says that these tenets concern 'established institutional ideals like the rule of law, the separation of powers, and democratic accountability' (p. 172).

${ }^{13}$ Brennan might argue for something similar, given his views on governmental decision making: 'citizens have at least as strong grounds as defendants to expect competence from government officials and decision makers as a matter of right' (2016, p. 156).
} 
Accountability: Political decisions must be made public and be open to public scrutiny and criticism by a press that are free of any political institution.

When a government and the political institutions it works within satisfy the above conditions, I will say that it is politically sound. Supposing that all four of these conditions are met by parties A \& B, they are then politically sound. Well, whatever negative or positive impacts there are for the governed, such impacts will be largely similar whichever political party gains power.

The example is very simplistic, but it provides us with a means of determining how competent voters should be. For in this imaginary example, it seems that the voters needn't be particularly competent at all. For, no matter which way they vote, the outcome will be relatively identical. So, their competence would make no difference to the consequences of the vote. This is clearly not the case for the jury example. One way to put this is in terms of thresholds: the threshold for voter competence is very low in cases where the consequences of the vote will be negligible regardless of which way the voters decide. For juries, the threshold for jury competence is always high.

We can think of competency thresholds in terms of the weight of the requirement there is to be competent. Consider the competence required to put together furniture. If I buy a piece of flat packed furniture with all the screw holes pre-drilled, screws provided, and simple instructions for putting it together, then I needn't be highly competent in putting together furniture. I'll just need some basic reading skills, minor abilities in manual labour, and perhaps the right tools to screw together the various parts. But if I'm building the furniture from scratch, cutting the correct lengths of wood, sanding it down, varnishing, painting, measuring and drilling, to get it all to correct lengths, shapes and sizes, and to get the furniture looking like a completed project, then I require a higher amount of competence. I'll need skills in woodwork, painting and sanding, and in using various relevant tools. In this second case, the threshold for the competence required to complete the task is higher than in the first case.

In the context of voters, a competency threshold determines how much competence an individual voter, or a collective electorate must have - that is, how weighty the requirements are on voters to be competent. This threshold goes up and down, depending on features of the context. The feature we are exploring is the significance of the consequences of the vote. When the significance of a vote is low, so is the threshold for competence, and conversely when the significance is high.

Let's now extend the example to make it more comparable with current western democracies. So, suppose that both A \& B exhibit political soundness, but also that they typically receive around $85 \%$ of the vote share. So, in a first past the post system, A or B are highly likely 
to be elected into power. A \& B have rivals though: C \& D. C is a politically sound emerging party, and $\mathrm{D}$ is politically unsound for some reason, say, because its political leaders lack the requisite competence to govern, or because its policies are unjustified. C \& D typically receive the remaining $15 \%$ of the vote share. If $\mathrm{C}$ gets into power, the prospects for the governed will be almost as good as if $\mathrm{A}$ or $\mathrm{B}$ get into power, but if $\mathrm{D}$ is elected to power, the prospects will be significantly worse.

Here we have a situation in which the competence of the voters does make a significant difference to the outcome, but one that is mitigated by various factors. For instance, suppose the more competent the voters are, the more likely they are to vote for A or B. That seems to increase the obligation on voters to be competent so as to avoid voting for especially D. However, the threshold for this obligation is low since it's highly unlikely that D will be elected because A \& B typically receive $85 \%$ of the voting share in this democracy. So, voters need to be competent enough to acknowledge the problems with $\mathrm{D}$, and to some extent $\mathrm{C}$, but that's a relatively modest requirement.

I want to press this argument further by considering a third variation on the example. Before I do though, I want to consider whether any actual representative democratic elections have been held that are similar to either of the above examples. In particular, have any of them had parties that satisfy the four conditions above? Although this is an empirical question, it looks reasonable to say that representative elections in the UK, say, from 1997 until 2015, have met these conditions. ${ }^{14}$ In the UK, political parties carefully scrutinise and publicly defend their various policies, which are meant for the benefit of the people governed. The system of government in the UK parliament is internally democratic and highly scrutinised from within and by the national free press. Moreover, members of parliament go through a lengthy process of checks before being selected as candidates to stand as representatives in local elections, and so must have the competence required to participate in representative politics. It seems likely, in my view, that recent elections in the UK parliament have met the four conditions above. Moreover, this will be true for many - perhaps the majority - of representative democracies in other countries over the last several decades and longer.

We can provide some intuitive evidence for this from an acknowledgement of a somewhat negative assumption. Many people who are eligible to vote in a large democracy either choose not to vote, or don't inform themselves to any significant degree before choosing how to vote. This is often due to a perception of the inconsequentiality of their vote. There are two respects in which

${ }_{14}$ Particularly since the constitutional changes brought in by the Blair labour government from 1997. However, things have been quite unstable for the UK government from 2017-2019, and during that time it may fail to exhibit political soundness. 
a vote could be considered inconsequential. The first is that a vote makes no difference because there are huge numbers of voters (Brennan 2011, p. 710). The second is that political parties regularly offer the same, or similar policies, shaped by the same economic climate, and bound by the same political constitution. Sometimes people say they don't vote because 'it's all just the same', meaning that their vote makes no difference because political parties are not particularly different from each other. So, even if the outcome of their vote were to decide between one party being elected rather than another, then the impact on their lives would still not change in aggregate. This is indicative evidence of the perception amongst voters that there will be little significant change to their overall wellbeing whomever they vote for. In my view, this perception is correct, for many representative democracies at least, even if the perception is somewhat negative. Moreover, it's enhanced by data showing that the turnout for some recent referenda has been higher than for representative elections, possibly because people take themselves to be making a decision in which there is a significant difference either way they vote. ${ }^{15}$

Let's now consider the third variation on the example. Imagine the situation from the second example with parties A - D, but where parties A and B have taken a radical turn in their socio-economic policies, and have each appointed party leaders who are unproven and represent risky leadership options. Here the voters must be careful. The outcome of the vote could bring about harmful consequences for the governed, and they need to give the political parties closer attention in their reasoning and deliberation. Perhaps the parties lack political soundness in their different respects, and the voters ought to tread more carefully when gathering evidence to answer the core voter question. In threshold terms, the voters should have a higher amount of competence than they should have in the previous example since the consequences of the vote could be more significant.

It may be that voter competence below the required threshold has been a partial cause of the election of various populist parties in recent world politics. A possible example is the election of Bolsonaro in Brazil. If the harmful policies of his party were available to the voters then they should have not elected his party to power. To do so, knowing what the outcome would be, yields the vote illegitimate since they have failed to vote competently. So, for some representative democratic decisions, there will be a significant difference for the governed depending on which political party gains power.

\footnotetext{
${ }^{15}$ For instance, voter turnout for Brexit in 2016 was $72.2 \%$, but for the general election in 2017 was $68.8 \%$, down again in 2019 to $67.2 \%$.
} 
In this section I have argued that the competence required by the principles set out in $\$ 3.1$ tracks the possible consequences of an electoral decision. In some cases, the competence required will be very low, in other cases it will be higher. In the final section I consider the implications of this argument for the right to vote, and the obligations on government.

\section{Restricted Suffrage and the Obligations on Government}

We have seen that citizens who vote require competence, to different degrees, to make a vote legitimate. Legitimacy is clearly a valuable property of a democratic decision, so how can we ensure we have it? There are at least three possible options. First, the electorate could be trained to be sufficiently competent. Second, suffrage could be restricted to the competent alone. Third, the competence required by the electorate could be minimised to ensure that citizens can satisfy it. The first option is a proposal for improved citizenship education. This may be helpful and go some way to enhancing the requisite competence of the electorate. However, this issue has been debated at length ${ }^{16}$ and so I'll focus more on the second and third options, particularly since the third follows from my arguments in $\$ 3.2$.

Could restricting suffrage to the competent alone be a way of ensuring we have legitimate electoral decisions? One of the reasons that Brennan develops the argument he does is because he wants to argue for a restriction to voting rights..$^{17}$ Now, I agree that a country's citizens will not always satisfy their competency obligations. There is some evidence to indicate that voters are not typically rational (Caplan 2007; Somin 2013), and hence will likely fall below the required competency threshold, particularly when the threshold is high. Hence, in at least some cases, electoral decisions will not be legitimate. Nevertheless, I wish to show that restricting suffrage to those who are competent doesn't guarantee legitimate outcomes.

Restricting voting rights to the competent alone is comparable to only changing jury members when it's been revealed that they are incompetent in an important respect that will likely yield the outcome of their decision illegitimate. For instance, if the jury member has been discovered to harbour severe prejudices against the defendant on the grounds of gender, or belongs to a racist group, or has been bribed to vote a particular way. In the jury case it seems morally required to remove the jury member under such circumstances. However, in the case of

\footnotetext{
${ }^{16}$ For instance, see the collections by McDonough and Feinberg (2005) and Macleod and Tappolet (2019). ${ }^{17}$ Although he does propose ways of retaining unrestricted suffrage, but where a competent 'epistocratic council' can 'veto any (or almost any) political decisions made by the general electorate or its representatives' (2016, p. 216).
} 
elections, there is a problem with the idea of restricting suffrage rights. For, even if you restrict voting rights to those who are competent, you can't guarantee a legitimate decision-making process that satisfies the competence obligation. Why should this be the case? Well, consider the following example.

There is a general election approaching in a country $C$, which has a population of 40 million eligible voters. Now, suppose that in order for these voters to keep their right to vote, they must meet a certain competency threshold determined by a competency exam (see Brennan 2016, pp. 211-14). We could determine the competence required for this exam along the lines of the argument from $\$ 3.2$ in that we set a threshold for competence given the consequences of the election for the governed. To pass the exam, citizens in $C$ must be able to exhibit a certain predetermined amount of political and economic knowledge. Moreover, would-be voters must be able to show, through an implicit bias test, that they don't hold any significantly problematic biases, and any biases you do have are presented to them so that they're aware of them whilst deliberating.

Suppose that the consequences of the vote will be significant - the voters' decision will determine the consequences for the governed, in a similar way to the third example from \$3.2. As such, we might imagine that the bar is quite high on these tests and exams and only $1 \%$ of the population in $C$ passes. That leaves 400,000 citizens with the right to vote. In this situation, will the competence obligation be satisfied? Only partially. For, if the tests and exams do the correct work, then we can guarantee that the decision will be made by a competent and morally reasonable deliberative body. That is, they will satisfy two of the three principles set out in $\$ 3.1$, namely, 'Epistemic Capability' and 'Epistemic Competence'. However, we can never guarantee that the decision will be based on competent and morally reasonable deliberation. That is, we can never guarantee that the electorate can satisfy the 'Proper Basing' principle. For, people can still cast deviant votes, make their decision based on a coin toss, read it in the tea leaves, or be paid off for their votes, amongst the many ways in which the decision could be arrived at incompetently. Hence, guaranteeing the competence of the electorate through restricted suffrage does not guarantee a legitimate electoral decision. So, even if a representative election is likely to be illegitimate, then this does not clearly support restricting votes to the competent alone.

Despite this, there is a way of supporting restricted suffrage to the competent that arises from the argument in \$3.2. Recall the notion of 'political soundness'. A politically sound government is one that satisfies the principles similar to those stated in \$3.2. There are two reasons, at least, for why political soundness in an election would be desirable. First, because an elected sound government will lead to better prospects for the governed. Second, because when parties in a general election are politically sound, there can be greater voter participation without the vote 
being illegitimate. This is because casting a vote in circumstances where all of the political parties are politically sound requires the voters to have a lower level of competency according to the principles of the competence obligation. Given this, many more people can take part without failing in their obligations.

Now, the problem with arguments, like those of Brennan, which look to show that the democratic process is illegitimate, is that they seek to place obligations on voters to avoid choosing governments that will lead to significant harm for the governed. It's for this reason that he chose the election of the Nazi party as a key example. However, this puts an unfairly high obligation on even a highly competent electorate. Another way of placing the obligation is on governments to be sound so that the voter's choice is always for a good option. That is, the voters should always be looking to choose the best option from a range of sound options. So, we have here not an obligation on the voters to be competent, but on the government, and the parties being selected, to be politically sound. To return to an earlier analogy, if the government are politically sound, it is like giving the voters flat-packed furniture to construct, whereas if they are unsound, it is more like requiring them to build furniture from scratch. The voters need more competence in the former case than the latter.

Perhaps surprisingly, we have generated an argument for restricted suffrage from the other direction. For, an obligation on the government to be sound may be better achieved in circumstances of limited suffrage. This is because governments will be better if they must work harder to justify their policies and decisions to a more competent electorate. ${ }^{18} \mathrm{~A}$ more competent electorate could, in theory, have more economic and political knowledge, foster less biases, be better at deliberating, and be less convinced by political rhetoric than a non-competent electorate. During the run up to an election, then, a party seeking votes to gain political power will have to work harder to justify policies, and will need to select, very carefully, the representatives to stand in each constituency.

Although this provides us with a reason to support restricted suffrage, I want to raise two concerns for this type of argument. First, why think that a restricted number of competent voters would lead to more justified policies in a country with a highly competent free media and press? In liberal democracies, the free press and media heavily scrutinise each major policy put forward by each political party and are highly experienced at interrogating politicians to put their views and policies under pressure. There doesn't seem to be any particular reason why simply having voters

\footnotetext{
${ }^{18}$ Moreover, some (Cohen 1997) argue that their policies will be more democratically legitimate when there is enhanced public deliberation.
} 
with a high level of competence, which may well be lower than the competence of the free press, ought to lead to more carefully thought out policies. To restrict votes for this reason could simply be superfluous in a context where the free press is highly competent, and where they heavily scrutinise parties and their policies.

A second, more general concern, is that all this discussion has given us is a reason for restricted suffrage which must be balanced against other reasons for unrestricted suffrage. Restricting suffrage to improve political soundness looks like a reason for restricted suffrage that carries a fairly low weight and will be easily outweighed by other considerations. For, even if a political party's policies will be more justified under circumstances of limited suffrage, this reason looks to be of lower weight than, say, the intrinsic value in distributing votes equally, or the historical importance in ensuring that all citizens have a say in how they are governed.

This leads us back to the idea that the central issue concerning representative democracy is not around voting rights. Rather, it is about the obligations on voters to be competent and on government to be politically sound. And those advocating restricted suffrage on the basis of voter incompetence don't place a high enough obligation on political parties. If they did, they would recognise that the more sound the government, the lower the competence of the voters must be. In elections, there is an obligation on the political system to present voters with a range of good options, not simply on voters to get it right which party will harm them and which will benefit them. Where political institutions are sound, and governmental obligations are satisfied, the legitimacy of electing those governments will follow.

Finally, what does this mean for voters? Well, in some circumstances, the obligation on voters to be competent will be high. But I have been arguing that the obligation should be low, and will be low, if governments fulfil their obligations. However, if voters have a low obligation to be competent, does this mean that they shouldn't take much interest in informing themselves on political matters? Not at all. For, informing themselves properly means that they can vote for the party that best serves their own interests, or the interests they believe to be best for the nation. Even if voting in an election will have a good outcome no matter which party gets into power, those parties still have different policies that meet different interests. This gives voters a reason to stay politically informed. Moreover, keeping oneself politically informed will help to ensure political soundness since political parties will need to justify their policies to the wider voting public.

\section{References}

Bohman, James (1996) Public Deliberation. Cambridge, MA: MIT Press. 
Brennan, Geoffrey and Loren Lomasky (1993) Democracy and Decision. Cambridge: Cambridge University Press.

Brennan, Jason (2011) 'The Right to a Competent Electorate,' The Philosophical Quarterly 61, 245, pp. 700-24.

Brennan, Jason (2016) Against Democracy. Princeton, NJ: Princeton University Press.

Caplan, Bryan (2007) The Myth of the Rational Voter. Princeton, NJ: Princeton University Press.

Christiano, Thomas (1995) 'Voting and Democracy,' Canadian Journal of Philosophy 25, 3, pp. 395414.

Cohen, Joshua (1997) 'Procedure and Substance in Deliberative Democracy,' in James Bohman and William Rehg (eds) Deliberative Democracy: Essays on Reason and Politics. London: MIT Press.

Estlund, David (2003) 'Why Not Epistocracy?’ in N. Reshotko (ed.) Desire, Identity, and Existence: Essays in Honor of T. M. Penner. Kelowna: Academic Printing \& Publishing, 53-69.

Estlund, David (2008) Democratic Authority: A Philosophical Framework. Princeton, NJ: Princeton University Press.

Goldman, Alvin (1999) Knowledge in a Social World. Oxford: Oxford University Press.

Landemore, Hélène (2012) Democratic Reason: Politics, Collective Intelligence, and the Rule of the Many. Princeton, NJ: Princeton University Press.

Lever, Annabelle (2016) 'Must We Vote for the Common Good?' Political Ethics. Emily Crookston, David Killoren and Jon Trerise (eds.). London: Routledge.

Macleod, Colin and Tappolet, Christine (2019) Philosophical Perspectives on Moral and Civic Education: Shaping Citizens and Their Schools. New York: Routledge.

Manin, Bernard (1987) 'On Legitimacy and Political Deliberation,' Political Theory, 15, pp. 338-368.

May, Kenneth O. (1952) 'A Set of Independent, Necessary, and Sufficient Conditions for Simple Majority Decision,' Econometrica, 20, 4, pp. 680-84.

Mele, Alfred (2006) 'Self-Deception and Delusions,' European Journal of Analytic Philosophy 2, 1, pp. 109-124.

McDonough, Kevin and Feinberg, Walter (2005) Citizenship and Education in Liberal-Democratic Societies: Teaching for Cosmopolitan V alues and Collective Identities. Oxford: Oxford University Press.

Mill, John Stuart (1991) Considerations on Representative Government. Buffalo, NY: Prometheus Books, originally published 1861 .

Mulligan, Thomas (2018) 'Plural Voting for the Twenty-First Century,' The Philosophical Quarterly, 68, 286-306.

Pettit, Philip (2017) Republicanism: A Theory of Freedom and Government. Oxford: Oxford University Press. 
Pitkin, Hannah (1965) 'Obligation and Consent - I,' The American Political Science Review, 59, 4, pp. 990-999.

Pitkin, Hannah (1966) 'Obligation and Consent - II,' The American Political Science Review, 60, 1, pp. $39-52$.

Rawls, John (1999) A Theory of Justice (revised edition). Cambridge, MA: Harvard University Press.

Rousseau, Jean-Jacques (1997) The Social Contract and Other Later Political Writings. Victor Gourevitch (ed. and trans.). Cambridge: Cambridge University Press, originally published 1762.

Saunders, Ben (2012) 'Democratic politics between the market and the forum,' Political Studies Review, 10, 1, pp. 23-35.

Silva, Paul (2015) 'On Doxastic Justification and Properly Basing One’s Beliefs,' Erkenntnis, 80, 5, pp. 945-55.

Somin, Ilya (2013) Democracy and Political Ignorance. Stanford: Stanford University Press.

Waldron, Jeremy (1998) 'Participation: the Right of Rights,' Proceedings of the Aristotelian Society, 98, pp. 307-37.

Watkins, Jonathan, Wulaningsih, Wahyu, Da Zhou, Charlie, et al. (2017) 'Effects of health and social care spending constraints on mortality in England: a time trend analysis,' BMJ Open 7, pp. 1-9. 